\title{
Effect of kit ligand on natriuretic peptide precursor $C$ and oocyte maturation in cattle
}

\author{
Paula F Lima ${ }^{1}$, Cinthia M Ormond ${ }^{1}$, Ester S Caixeta ${ }^{1}$, Rodrigo G Barros ${ }^{1}$, \\ Christopher A Price ${ }^{2, *}$ and José Buratini ${ }^{1, *}$ \\ ${ }^{1}$ Departamento de Fisiologia, Instituto de Biociências, Universidade Estadual Paulista, Rubião Junior, Botucatu, \\ São Paulo, Brazil and ${ }^{2}$ Centre de recherche en reproduction animale, Faculté de médecine vétérinaire, \\ Université de Montréal, St-Hyacinthe, Quebec, Canada \\ Correspondence should be addressed to J Buratini; Email: buratini@ibb.unesp.br \\ *(C A Price and I Buratini contributed equally to this work)
}

\begin{abstract}
In vitro maturation (IVM) of oocytes in cattle is inefficient, and there is great interest in the development of approaches to improve maturation and fertilization rates. Intraovarian signalling molecules are being explored as potential additives to IVM media. One such factor is kit ligand (KITL), which stimulates the growth of oocytes. We determined if KITL enhances oocyte maturation in cattle. The two main isoforms of KITL (KITL1 and KITL2) were expressed in bovine cumulus-oocyte complexes (COC), and levels of mRNA increased during FSH-stimulated IVM. The addition of KITL to the culture medium increased the percentage of oocytes that reached meiosis II but did not affect cumulus expansion after $22 \mathrm{~h}$ of IVM. Addition of KITL reduced the levels of mRNA encoding natriuretic peptide precursor C (NPPC), a protein that holds oocytes in meiotic arrest, and increased the levels of mRNA encoding YBX2, an oocyte-specific factor involved in meiosis. Removal of the oocyte from the COC resulted in increased KITL mRNA levels and decreased NPPC mRNA levels in cumulus cells, and addition of denuded oocytes reversed these effects. Taken together, our results suggest that KITL enhances bovine oocyte nuclear maturation through a mechanism that involves NPPC, and that the oocyte regulates cumulus expression of $K I T L$ mRNA.

Reproduction (2016) 152 481-489
\end{abstract}

\section{Introduction}

Ovulation is induced by the luteinizing hormone (LH) surge, which causes the increased expression of epidermal growth factor (EGF)-like proteins in granulosa and cumulus cells, and subsequent induction of prostaglandin-endoperoxide synthase 2 (PTGS2) mRNA/protein and prostaglandin secretion. Prostaglandins induce the expansion of the cumulus complex and proteolytic degradation of the follicle wall, and are involved in oocyte nuclear maturation (Richards 2005, Reizel et al. 2010, Prochazka et al. 2012, Marei et al. 2014).

Before the LH surge, oocytes are held in meiotic arrest by high intraoocyte levels of cAMP that are maintained at least in part by the transfer of cGMP from cumulus cells to the oocyte through gap junctions (Shuhaibar et al. 2015). The generation of cGMP is driven by natriuretic peptide precursor C (NPPC), which is secreted from granulosa and cumulus cells and activates natriuretic peptide receptor B (NPR2) on cumulus cells (Zhang et al. 2010a, Franciosi et al. 2014, De Cesaro et al. 2015). Loss of NPPC expression results in resumption of meiosis (Zhang et al. 2010a, Kawamura et al. 2011, Robinson et al. 2012) and addition of NPPC to cumulus-oocyte complexes (COC) in vitro delayed resumption (Zhang et al. 2010a, Franciosi et al. 2014). During follicle growth, NPPC levels are high, and are decreased by hCG in preovulatory follicles (Liu et al. 2014). Thus, growing follicles produce quantities of NPPC sufficient to prevent premature resumption of meiosis, and the preovulatory LH surge relieves this brake on oocyte maturation.

Cytoplasmic maturation must be tightly synchronized with nuclear maturation for the oocyte to achieve developmental competence. Accumulation of mRNA stocks that allow protein production until the embryo becomes transcriptionally competent is a crucial component of cytoplasmic maturation since transcriptional activity progressively decreases as chromatin condensation advances in the germinal vesicle (Hyttel et al. 1986, Lodde et al. 2007). Y-box binding protein 2 (YBX2) appears to be a key regulator in this context; YBX2 increases mRNA content, mRNA stability and protein synthesis in mouse oocytes 
(Yu et al. 2004, Medvedev et al. 2011). In the bovine oocyte, YBX2 expression decreases as maturation progresses from the germinal vesicle stage to metaphase II (Vigneault et al. 2009).

Another factor involved in oocyte maturation is kit ligand (KITL), which is secreted from granulosa cells and acts on receptors (KIT) on the oocyte (Hutt et al. 2006, Thomas \& Vanderhyden 2006, Celestino et al. 2010). Alternative splicing of KITL mRNA results in a fulllength and a truncated protein, termed KITL1 and KITL2 respectively, and both are biologically active (Brannan et al. 1991, Huang et al. 1992, Zhou et al. 1994, Kawaguchi et al. 2007). Although KITL is well known to stimulate growth and survival of oocytes (Packer et al. 1994, Ismail et al. 1997, Thomas et al. 2008), its effects on nuclear maturation are controversial: addition of KITL to denuded rat oocytes reduced the rate of the 1 st polar body extrusion after $14 \mathrm{~h}$ culture (Ismail et al. $1996,1997)$, whereas it increased the rate of the $1 \mathrm{st}$ polar body extrusion after $22 \mathrm{~h}$ in mice (Ye et al. 2009).

It is well established that the oocyte regulates cumulus cell function in mice, but the role the oocyte plays in cattle is less clear. The oocyte is required for cumulus glycolysis and expansion in mice (Eppig 2005, Sugiura et al. 2005, Vanderhyden 1993) but not in cattle (Ralph et al. 1995, Sutton et al. 2003). Removal of the oocyte from the COC (oocytectomy) in mice reduced the levels of mRNA encoding certain genes in cumulus cells including Nppc (Lee et al. 2013), and increased those of other genes including Kitl (Joyce et al. 1999); a microarray study with bovine oocytectomized cumulus cells did not identify NPPC or KITL as genes affected by the oocyte (Regassa et al. 2011). The inhibitory effect of the murine oocyte on cumulus cell Kitl mRNA levels is likely mediated through the secretion of growth/ differentiation factor 9 (Gdf9) (Joyce et al. 2000), although another oocyte-secreted factor, bone morphogenetic factor (Bmp) 15, has been shown to stimulate cumulus Kitl mRNA levels in rodents (Otsuka \& Shimasaki 2002, Thomas et al. 2005, Miyoshi et al. 2012).

It is not known if the bovine oocyte regulates KITL or NPPC expression in cattle, and although NPPC has been shown to delay meiotic resumption in cattle (Franciosi et al. 2014), the impact of KITL on meiotic resumption in cattle has not been reported. In this study, we tested the hypothesis that KITL signalling regulates COC maturation under the influence of the oocyte in the cow. The specific objectives were to determine the regulation of KITL expression by the oocyte and putative oocyte-secreted factors, and to measure the effects of KITL on cumulus expansion, NPPC mRNA levels and oocyte maturation.

\section{Materials and methods}

Unless specified, all chemicals and reagents were purchased from Sigma.

\section{Experimental design}

The patterns of expression of KITL1and KITL2 mRNA in cumulus cells and of KIT mRNA in oocytes were evaluated during IVM at $0,4,8,12,16$ and $22 \mathrm{~h}$ ( $n=4 /$ time). To investigate the effects of oocyte-secreted factors on the abundance of KITL1 mRNA in cumulus cells, the culture medium was supplemented with graded doses of recombinant BMP15 $(n=4 /$ dose), FGF8 ( $n=5 /$ dose) or FGF17 $(n=4 /$ dose; R\&D Systems). The effect of KITL on COC maturation was determined by culturing COC for $22 \mathrm{~h}$ with $0,10,50$ or $100 \mathrm{ng} / \mathrm{mL}$ recombinant KITL1 (R\&D Systems) to evaluate cumulus expansion and abundance of mRNA encoding key proteins involved in expansion ( $n=4 /$ dose), and the progression of the oocyte through meiosis ( $n=9 /$ dose) as well as key genes involved in nuclear maturation ( $n=4 /$ dose). The effect of the oocyte and oocyte-secreted factors on the expression of KITL and NPPC in cumulus cells was tested by the comparison of mRNA levels from intact COCs, oocytectomized COCs and oocytectomized COCs cultured with denuded oocytes ( 1 denuded oocyte/ $\mu \mathrm{L} ; n=4 /$ group).

\section{In vitro maturation}

Ovaries of adult cows (predominantly Nellore, Bos indicus) were obtained at an abattoir local to the São Paulo State University campus in Botucatu and transported to the laboratory in saline solution $(0.9 \% \mathrm{NaCl})$ at $37^{\circ} \mathrm{C}$. COCs were aspirated from 3 to $8 \mathrm{~mm}$ diameter follicles with an 18 gauge needle and pooled in a $15 \mathrm{~mL}$ conical tube. After sedimentation, COCs were recovered and selected using a stereomicroscope. Only COCs with homogeneous cytoplasm and compact multilayer of cumulus cells were used (Grade 1 and 2). COCs were washed and transferred in groups of 20 to a $100 \mu \mathrm{L}$ drop of maturation medium, TCM199 containing Earle's salts supplemented with $1 \mu \mathrm{g} / \mathrm{mL}$ porcine $\mathrm{FSH}$ (equivalent to 0.002 IU; Folltropin-V Bioniche Animal Health, Belleville ON, Canada), $10 \mathrm{IU} / \mathrm{mL} \mathrm{LH}$ (Lutropin-V, Bioniche Animal Health), $22 \mu \mathrm{g} / \mathrm{mL}$ sodium pyruvate, $75 \mu \mathrm{g} / \mathrm{ml}$ amicacin, $4 \mathrm{mg} / \mathrm{mL}$ BSA and growth factors. Drops were covered with mineral oil and incubated at $38.5^{\circ} \mathrm{C}$ in $5 \% \mathrm{CO}_{2}$ in humidified air.

\section{Oocytectomy}

Oocyte-cumulus complexes were placed in $200 \mu \mathrm{L}$ drops of TCM199 partially covered with mineral oil, and the cytoplasm of the oocytes was removed with a micromanipulator as described (Buccione et al. 1990) with modifications (Paradis et al. 2010).

\section{Assessment of cumulus expansion}

Cumulus expansion was visually assessed at $22 \mathrm{~h}$ of culture according to a subjective scoring system. Grades 1-3 were attributed to increasing degrees of expansion (Grade 1: poor expansion, characterized by few morphological changes compared with before maturation; Grade 2: partial expansion, characterized by fair expansion but notable clusters lacking expansion; Grade 3: complete or nearly complete expansion (Machado et al. 2015). 
Table 1 Information of specific primers used for amplification in real-time PCR.

\begin{tabular}{|c|c|c|c|c|}
\hline Gene & Primer sequence & Fragment size (bp) & Annealing temperature $\left({ }^{\circ} \mathrm{C}\right)$ & Reference \\
\hline BMP15 & $\begin{array}{l}\text { F: 5'GTCAGCAGCCAAGAGGTAGTG3' } \\
\text { R: 5'CCCGAGGACATACTCCCTTAC3' }\end{array}$ & 360 & 59 & Caixeta et al. (2013a) \\
\hline GDF9 & $\begin{array}{l}\text { F: 5'TGGTCCTTGCTGAAGCATCTAGA3' } \\
\text { R: 5'ACAGTGTTGTAGAGGTGGCTTCT3' }\end{array}$ & 202 & 59 & Caixeta et al. (2013a) \\
\hline KIT & $\begin{array}{l}\text { F: 5'ATCATGAAGACCTGCTGGGATGCT3' } \\
\text { R: 5'GGGCTGCAGTTTGCTAAGTTGGAA3' }\end{array}$ & 128 & 60 & AF263827.1 \\
\hline YBX2 & $\begin{array}{l}\text { F: 5'GTGCTGGCAATCCAAGTCC3' } \\
\text { R: 5'CTTCTCTCCTTCCACGACATC3' }\end{array}$ & 118 & 60 & NM_001098126.2 \\
\hline KL1 & $\begin{array}{l}\text { F: 5'GTGTGATTTCCTCAACATCAAGTCC3' } \\
\text { R: 5'TGCTACTGCTGTCATTCCTAAGGG3' }\end{array}$ & 111 & 60 & NM_174375.2 \\
\hline$K L 2$ & $\begin{array}{l}\text { F: 5'AAGGGAAGGCCTCAAATTCCATTGAAGA3' } \\
\text { R: 5'AGCAAACCCGATCACAAGAGA3' }\end{array}$ & 92 & 60 & NM_174375.2 \\
\hline CCNB1 & $\begin{array}{l}\text { F: 5'GGATACCTATGTGCCCAAGAAG3' } \\
\text { R: 5'CCGATTTCTGGAGGGTACATTT3' }\end{array}$ & 96 & 60 & NM_001045872.1 \\
\hline NPPC & $\begin{array}{l}\text { F: 5'TCAGCCTCCTCGCATCT3' } \\
\text { R: 5'ACAGCTGGTGTTGTATCC3' }\end{array}$ & 101 & 60 & NM_174125.2 \\
\hline NPR2 & $\begin{array}{l}\text { F: 5'ATGACAGCATCAACCTGGACTGGA3' } \\
\text { R: 5'AGCACGAAACGACTATCCACCACA3' }\end{array}$ & 145 & 60 & NM_174126.2 \\
\hline PTGS2 & $\begin{array}{l}\text { F: 5'AAGCCTAGCACTTTCGGTGGAGAA3' } \\
\text { R: 5'TCCAGAGTGGGAAGAGCTTGCATT3' }\end{array}$ & 168 & 60 & Caixeta et al. (2013b) \\
\hline$C Y C-A$ & $\begin{array}{l}\text { F: 5'GCCATGGAGCGCTTTGG3' } \\
\text { R: 5'CCACAGTCAGCAATGGTGATCT3' }\end{array}$ & 65 & 60 & Machado et al. (2009) \\
\hline
\end{tabular}

$\mathrm{F}$, forward primer; $\mathrm{R}$, reverse primer.

\section{Meiosis progression: oocyte nuclear maturation}

Meiosis progression was assessed after $22 \mathrm{~h}$ of maturation. Oocytes were denuded by pipetting in PBS and stained for 20 min with Hoechst 33342 (1 mg/mL Invitrogen $\mathrm{H}-1399)$ under a UV excitation using epifluorescence microscopy, and stage of meiosis were determined and classified as metaphase I (MI) or telophase I/metaphase II (TI/MII).

\section{Gene expression analysis}

After culture, cumulus cells and oocytes from 20 COCs were mechanically separated by repeated pipetting in PBS without calcium and magnesium. Cumulus cells were transferred to $1.5 \mathrm{~mL}$ tubes, collected by centrifugation for $5 \mathrm{~min}$ at $700 \mathrm{~g}$ and frozen at $-80^{\circ} \mathrm{C}$ in $350 \mu \mathrm{L}$ of RNA extraction lysis buffer from the RNeasy kit (Qiagen). Total RNA was extracted using the RNeasy kit as recommended by the manufacturer. After purification, RNA samples were eluted in $30 \mu \mathrm{L}$ of RNAsefree water. Total RNA concentrations were measured by spectrophotometry using a NanoDrop ND 1000 (Thermo Scientific). Total RNA (100 ng/reaction for cumulus cells and $9 \mu \mathrm{l}$ of the RNA sample for oocytes) was incubated with

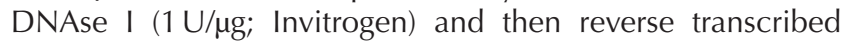
using oligo-dT primers and Omniscript (for cumulus cells) or Sensiscript (for oocytes) reverse transcriptases (Qiagen). The reagents were incubated at $37^{\circ} \mathrm{C}$ for $60 \mathrm{~min}$ and then at $93^{\circ} \mathrm{C}$ for $3 \mathrm{~min}$ for enzyme inactivation. Relative real-time RT-PCR analysis was performed with an $\mathrm{ABI} 7500$ thermocycler using Power SYBR Green PCR Master Mix (Applied Biosystems). The final volume of the PCR mix was $25 \mu \mathrm{L}$, and thermocycling conditions were: $95^{\circ} \mathrm{C}$ for $10 \mathrm{~min}(1 \mathrm{cycle})$, denaturing at $95^{\circ} \mathrm{C}$ for $10 \mathrm{~s}$ followed by annealing for $1 \mathrm{~min}$ (40 cycles). Primers for the housekeeping gene CYCA and for target genes PTCS2, BMP15 and GDF9 were as previously used and validated (Caixeta et al. 2013a,b). Primers to amplify bovine YBX2, CCNB1, KIT, KITL1, KITL2, NPPC and NPR2 were designed with PrimerQuest Tool and are shown in Table 1. The relative expression values for each gene were calculated using the $\Delta \Delta \mathrm{Ct}$ method with efficiency correction and using one control sample as calibrator (Pfaffl 2001). Cyclophilin-A was used as the housekeeping gene as previously validated in our laboratory (Caixeta et al. 2013a).

\section{Statistical analysis}

Maturation and cumulus expansion data were arcsine transformed before analysis, and gene expression data were transformed to logarithms when not normally distributed. The effects of treatments with growth factors on cumulus cell expansion, maturation and gene expression were tested by analysis of variance (ANOVA), and means were compared with the Tukey-Kramer HSD test using JMP software (SAS Institute, Cary, NC, USA). Differences were considered significant when $P<0.05$.

\section{Results}

\section{KITL1, KITL2 and KIT mRNA levels in COCs during IVM}

To determine whether $K I T L$ undergoes alternative splicing in cattle, primers were designed to span the potential splice junction, and PCR performed on cumulus cell RNA. Agarose gel electrophoresis revealed two bands, and sequencing identified one product lacking 84 nucleotides of exon 3 that corresponds to KITL2, and another product including exon 3 corresponding to KITL1. Subsequent real-time PCR was performed with primers specific to each splice variant. Average Ct values for KITL1 and KITL2 mRNA in cumulus cells were 28.8 and 29.3 cycles respectively. Relative abundance of KITL1 and KITL2 mRNA increased during IVM with 
A
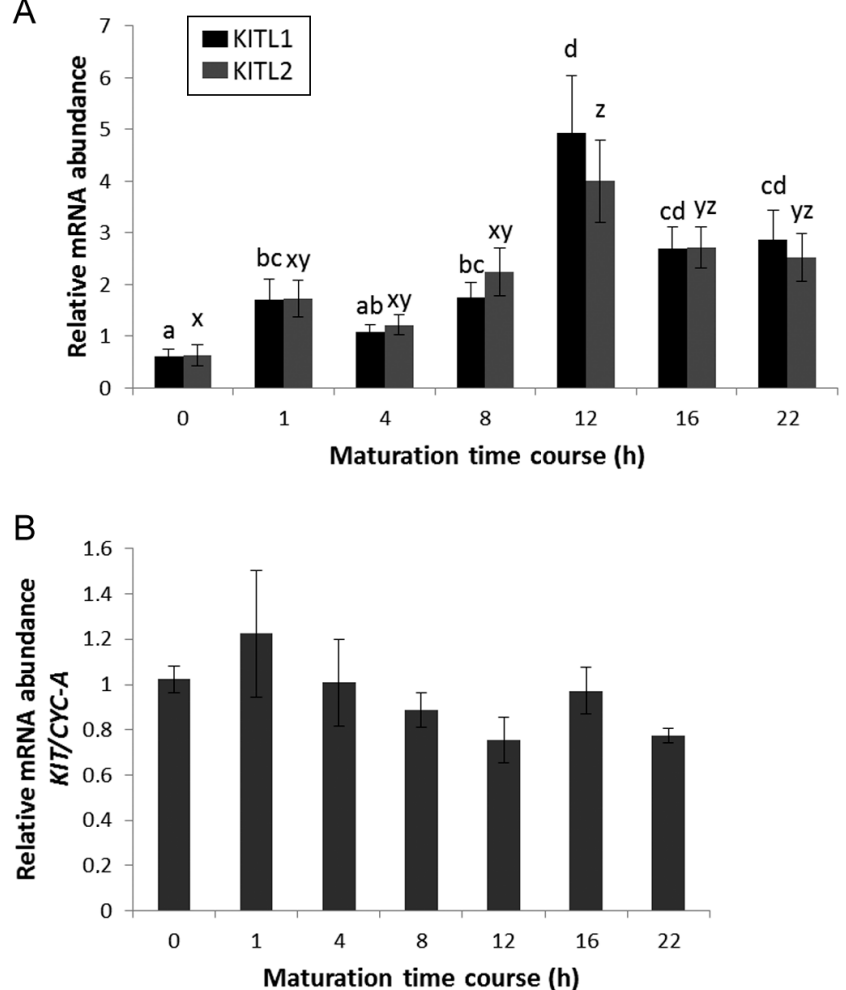

Figure 1 Abundance of KITL1, KITL2 (A) and KIT (B) mRNA in cumulus cells during IVM. Groups of immature COCs represent $0 \mathrm{~h}$. Messenger RNA abundance was measured by real-time PCR. Data are presented as mean values ( \pm S.E.M.) relative to a calibrator sample and were calculated by the $\Delta \Delta \mathrm{Ct}$ method with efficiency correction. Bars with different letters are significantly different (a, b, c for KITL1/x, y, z for KITL2; P<0.05). Data were derived from four independent replicates.

significantly greater levels at $12 \mathrm{~h}$ compared with $0-8 \mathrm{~h}$ (Fig. 1). The abundance of KIT mRNA in the oocyte did not vary during IVM.

\section{Effect of KITL on cumulus expansion and oocyte maturation}

Addition of recombinant KITL1 to IVM medium did not affect cumulus expansion, but significantly stimulated the progression of meiosis as indicated by the increased proportion of oocytes reaching meiosis II (Fig. 2). Furthermore, KITL1 increased the levels of mRNA encoding the germ cell-specific marker $Y B X 2$, but did not alter those encoding CCNB1, BMP15 and GDF9 in the oocyte, or NPR2 in cumulus cells (Fig. 3).

Addition of KITL1 decreased the abundance of NPPC mRNA in cumulus cell and had no effect on cumulus cell NPR2 or PTGS2 mRNA levels.

\section{Effects of the oocyte or oocyte-secreted factors on KITL mRNA levels}

Removal of the oocyte significantly increased the abundance of mRNA encoding KITL1 and KITL2 in cumulus
A
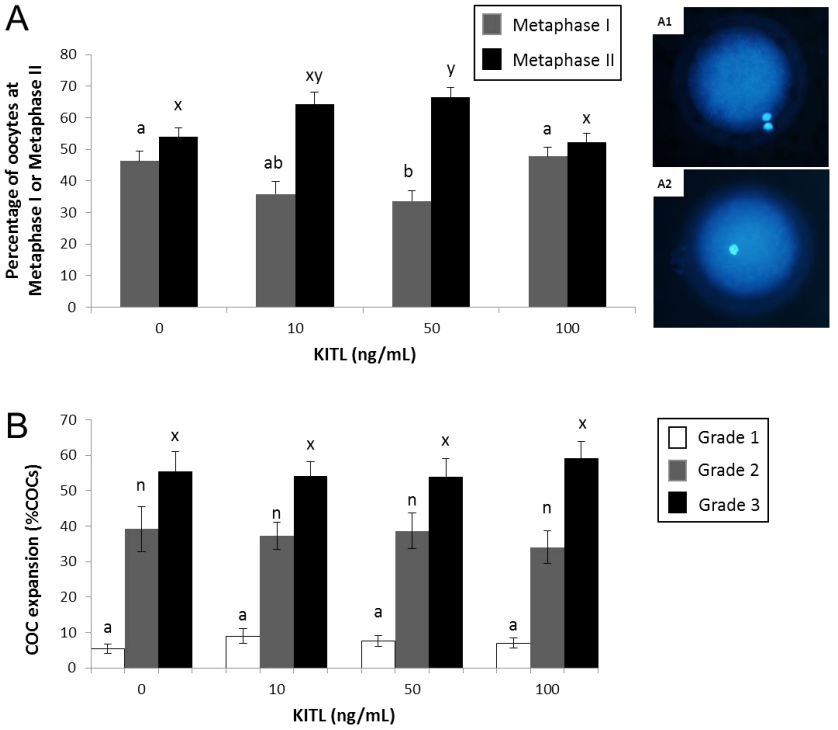

Figure 2 Effect of KITL1 on meiosis progression (A) and cumulus expansion (B) after $22 \mathrm{~h}$ of IVM. Oocytes were classified as MI (meiosis I; A1) or TI/MII (oocytes in the transition telophase I/ metaphase II and oocytes in metaphase II; A2). The degree of cumulus expansion was classified as grades 1 (poor expansion), 2 (partial expansion) and 3 (full expansion). Different letters within meiosis stages indicate significant differences $(P<0.05)$.
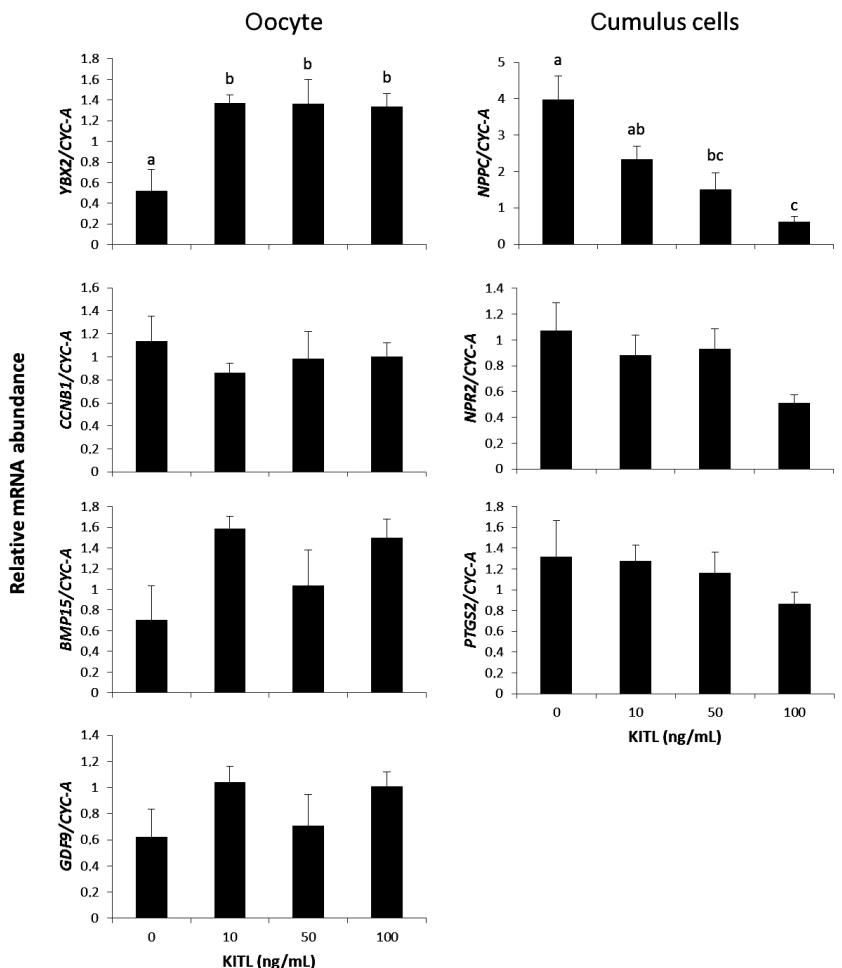

Figure 3 Effect of KITL1 on mRNA levels of genes regulating COC maturation in cumulus cells (NPPC, NPR2 and PTGS2) and in the oocyte (CCNB1, YBX2, BMP15 and GDF9). Messenger RNA abundance was measured by real-time PCR. Data are presented as mean values ( \pm S.E.M.) relative to a calibrator sample by the $\Delta \Delta \mathrm{Ct}$ method with efficiency correction. Bars with different letters are significantly different $(P<0.05)$. Data were derived from four independent replicates. 

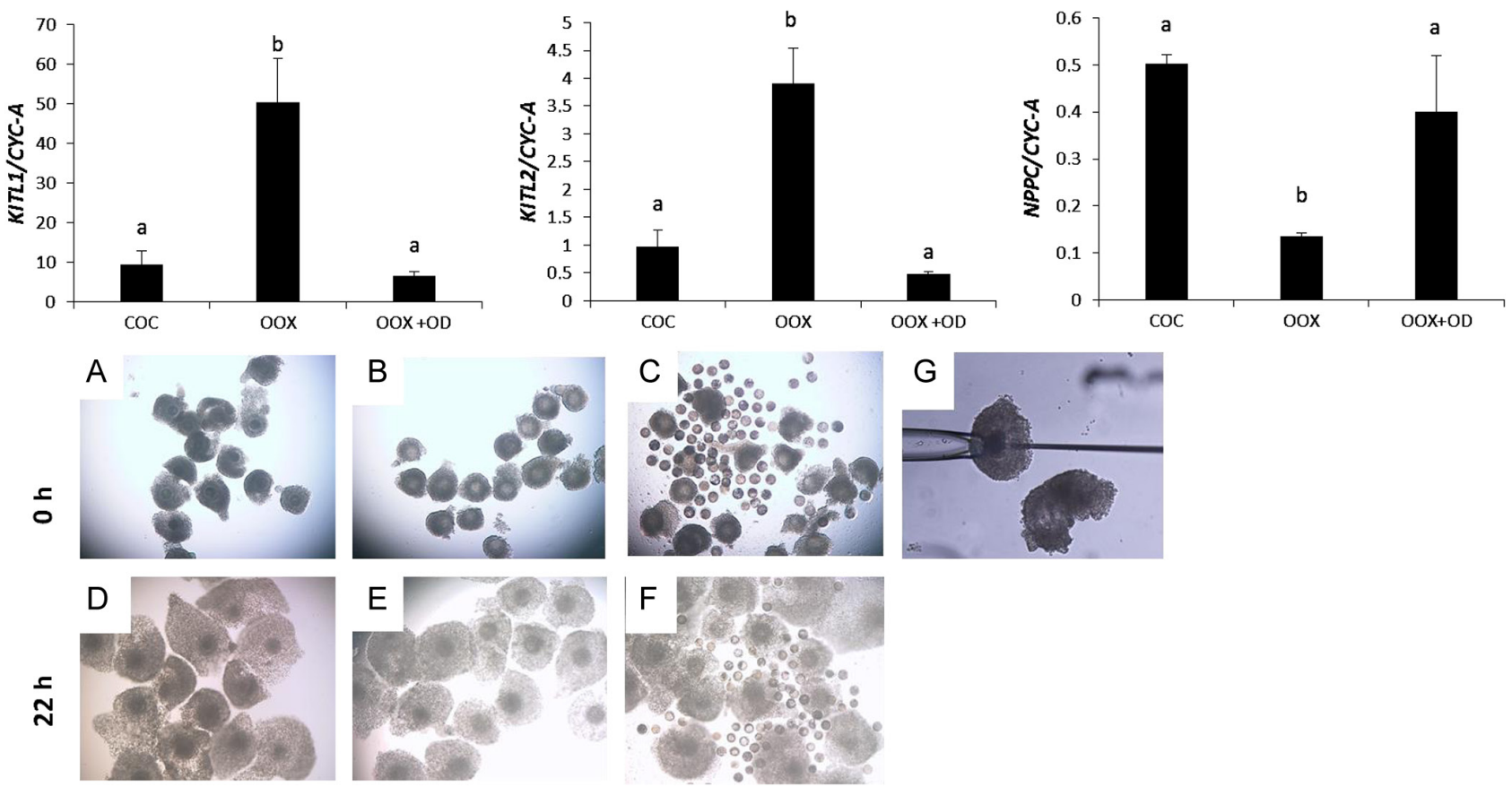

Figure 4 Effects of oocyte removal and oocyte replacement on KITL1, KITL2 and NPPC mRNA levels in cumulus cells. COCs were cultured intact (COC), oocytectomized (OOX) or oocytectomized with denuded oocytes (OOX+DO) for $22 \mathrm{~h}$. Messenger RNA abundance was measured by real-time PCR. Data are presented as mean values ( \pm S.E.M.) relative to a calibrator sample by the $\Delta \Delta$ Ct method with efficiency correction. Bars with different letters are significantly different $(P<0.05)$. Data were derived from four independent replicates. Ilustrative photomicrographs of culture groups before and after IVM (A and D: intact COCs; B and E: OOX; C and F: OOX plus denuded oocytes), and of the oocytectomy procedure $(\mathrm{G})$.

cells, and addition of denuded oocytes reversed this effect (Fig. 4). In the same samples, oocytectomy significantly decreased NPPC mRNA levels, which again was restored to control levels by coculture with denuded oocytes (Fig. 4).
The addition of FGF8 to intact COC in IVM medium for $22 \mathrm{~h}$ increased cumulus cell KITL1 and KITL2 but decreased NPPC mRNA levels, addition of BMP15 increased only KITL1 mRNA levels, addition of FGF10
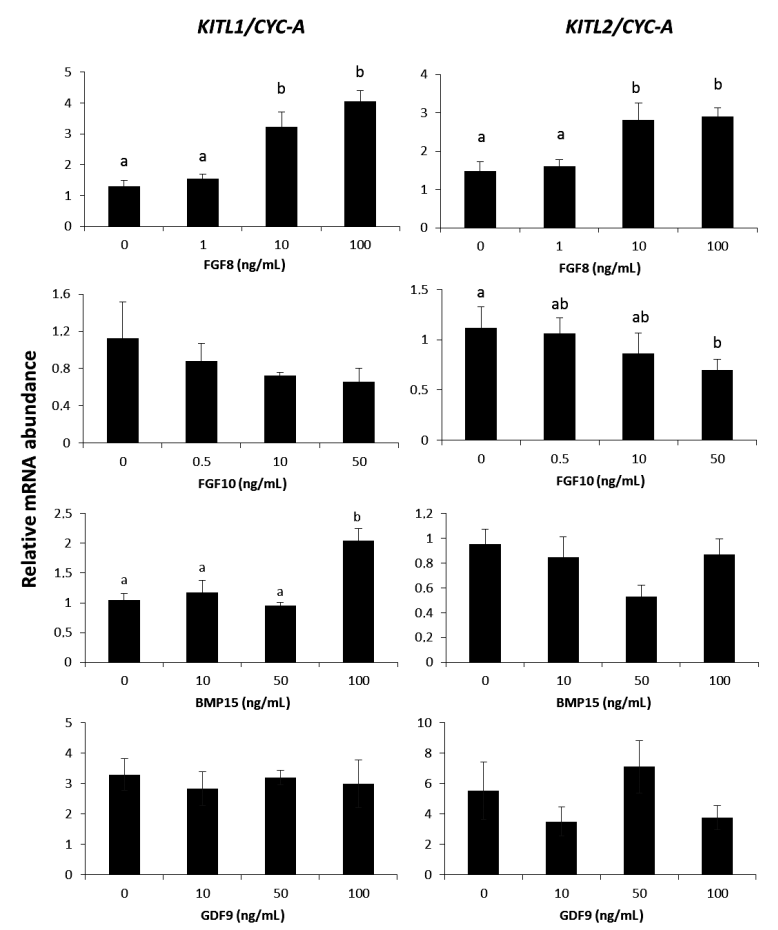
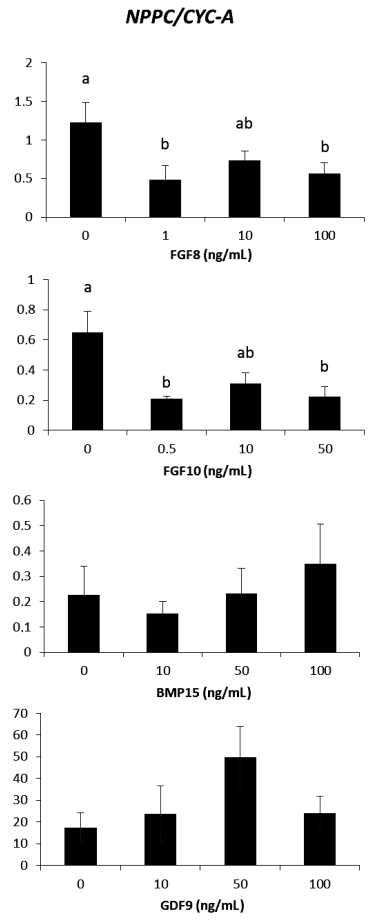

Figure 5 Effects of putative oocyte-secreted factors on KITL1, KITL2 and NPPC mRNA levels in cumulus cells. COCs were cultured with graded doses of FGF8, FGF10, BMP15 and GDF9 for $22 \mathrm{~h}$ of IVM. Messenger RNA abundance was measured by real-time PCR. Data are presented as mean values ( \pm S.E.M.) relative to a calibrator sample by the $\Delta \Delta \mathrm{Ct}$ method with efficiency correction. Bars with different letters are significantly different $(P<0.05)$. Data were derived from four independent replicates. 


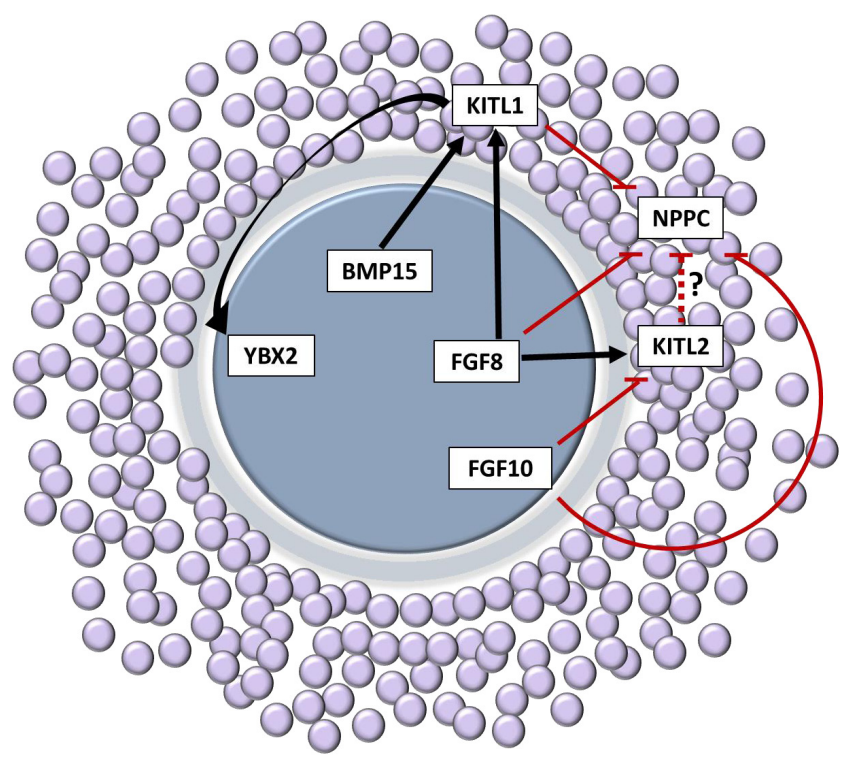

Figure 6 Illustrative model of the paracrine interaction of KITL, NPPC, YBX2 and oocyte-derived factors (BMP15, FGF8 and FGF10) in the bovine COC.

decreased KITL2 and NPPC mRNA abundance and addition of GDF9 had no effect on KITL1, KITL2 or NPPC mRNA expression (Fig. 5).

\section{Discussion}

In mice, the oocyte is critical for several cumulus cell functions including expansion, and regulates the levels of mRNA encoding Nppc and Kitl, two proteins involved in resumption of meiosis. In cattle, the oocyte is not necessary for expansion, and effects of the oocyte on cumulus cell NPPC and KITL mRNA levels have not previously been reported. In this study, we demonstrate that, surprisingly, the bovine oocyte regulates these two genes in a manner very similar to that previously observed in the mouse, and we show that KITL enhances nuclear maturation in the cow. We also link KITL and NPPC for the first time, demonstrating that KITL downregulates NPPC mRNA levels in cumulus cells, and suggesting that this is a mechanism by which KITL increases the maturation of the oocyte. A model depicting the paracrine interaction involving $\mathrm{KITL}$, NPPC, YBX2 and oocyte-derived factors in the bovine COC is proposed (Fig. 6).

One of the more interesting results of this study is the similarity in the response of cumulus cell KITL and NPPC mRNA levels to oocytectomy observed here in cattle with that previously observed in mice (Joyce et al. 1999, Lee et al. 2013). This appears to be unusual in that cumulus function in cattle, such as metabolism and expansion (Ralph et al. 1995, Sutton et al. 2003) and appears not to be impacted by the removal of the oocyte. Equally novel is the ability of denuded bovine oocytes to completely restore $K I T L$ and NPPC mRNA levels to those observed in intact COCs, suggesting the role of an oocyte-secreted factor (OSF). A previous study demonstrated the role of the bovine oocyte in maintaining cumulus cell health (Hussein et al. 2005); collectively, these data point to a role for the oocyte in cumulus function in cattle, but one that differs from that in the mouse.

In rodents, Gdf9 is an abundant OSF (Crawford \& McNatty 2012) and inhibits Kitl mRNA levels in cumulus cells (Joyce et al. 2000). The murine oocyte may therefore maintain low Kitl expression levels through the secretion of Gdf9 (Joyce et al. 2000, Otsuka and Shimasaki 2002, Thomas et al. 2005, Miyoshi et al. 2012), and thus removal of the oocyte increased Kit/ mRNA levels (Joyce et al. 1999). In the cow, however, it is believed that BMP15 is the more abundant OSF compared with GDF9 (Crawford \& McNatty 2012) and so the oocyte may not control cumulus KITL mRNA in the same manner. Moreover, a recent study points to a physiological and more effective action for the promature form of the heterodimer BMP15-GDF9 named cumulin in relation to BMP15 and GFD9 homodimers in monovular species (Mottershead et al. 2015). In this study, FGF8 and BMP15 stimulated KITL mRNA levels, as in the mouse, and FGF10 inhibited KITL mRNA abundance. Therefore, the increase in KITL mRNA levels following oocytectomy in cattle may be at least in part attributable to the loss of FGF10, and not to the influence of oocyte-derived FGF8 and BMP15 homodimer. The reduction in NPPC mRNA levels induced by FGF8 is likely mediated by KITL signalling given the stimulatory effect of FGF8 on KITL expression and the inhibitory effect of KITL on NPPC expression. In contrast, FGF10 appears to inhibit NPPC expression by a different mechanism since it decreased KITL2 mRNA levels without affecting those of KITL1. The decrease in NPPC expression induced by FGF10 is consistent with its previously reported stimulatory effect on oocyte nuclear maturation (Zhang et al. 2010b).

In this study, both KITL1 and KITL2 mRNA levels increased with time during cumulus expansion. This is consistent with the increase in Kitl mRNA levels observed in granulosa and cumulus cells in mice in response to eCG (Ismail et al. 1996, Ye et al. 2009). The effects of KITL on oocyte maturation are not yet clear. Addition of KITL to denuded rat oocytes reduced the rate of the $1 \mathrm{st}$ polar body extrusion after $14 \mathrm{~h}$ culture (Ismail et al. 1996), whereas it increased the rate of the 1 st polar body extrusion after $22 \mathrm{~h}$ in mice (Ye et al. 2009) and the rate of oocytes reaching MII in cattle (present study). The importance of this effect is not clear, as in mice, treatment with KITL did not enhance the rate of blastocyst development (Ye et al. 2009). The KITL-induced increase in rates of maturation in the mouse was associated with increased levels of Ccnb1 protein in Ml oocytes (Ye et al. 2009), whereas in this study, KITL did not alter CCNB1 mRNA levels in MII oocytes. As CCNB1 is involved in meiosis 1 , it is likely that the time point chosen in this study was too late to detect an effect of KITL. 
Addition of KITL1 to COC decreased the abundance of mRNA encoding NPPC, and this may offer an explanation for the mechanism of action of KITL. Resumption of meiosis is triggered by a decrease in cAMP levels in the oocyte, which is the result of decreased transfer of cAMP and cGMP from cumulus cells (Norris et al. 2009). There is no evidence that KITL alters cumulus cGMP levels, and KITL did not alter FSH-stimulated cAMP levels in rat granulosa-oocyte cocultures (Miyoshi et al. 2012). However, NPPC has been demonstrated to increase cumulus cell cGMP levels and maintain meiotic arrest in rodents and cattle (Zhang et al. 2010a, Franciosi et al. 2014); therefore, the decrease in NPPC mRNA caused by KITL observed here might be expected to lead to a decrease in NPPC signalling and of cGMP levels, and thus the resumption of meiosis. We are not aware of any other reports demonstrating the regulation of NPPC levels by KITL. In the present dataset, although the highest dose of KITL promoted the maximal decrease in NPPC mRNA abundance, it did not alter oocyte nuclear maturation. A possible explanation for this intriguing observation is that high doses of KITL may precociously and intensively suppress NPPC/NPR2 signalling leading to abrupt closure of gap junctions, which could be detrimental to meiosis resumption.

A further novel finding of this study is the stimulatory effect of KITL on oocyte YBX2 mRNA levels. In this study, we used oocytes from follicles $3-8 \mathrm{~mm}$ in diameter, which are predominantly at advanced stages of the germinal vesicle and with low transcriptional activity (Lodde et al. 2007, 2008), and oligo-dT primers in the RT-PCR strategy. Therefore, this result more likely reflects an increase in adenylated $Y B X 2 \mathrm{mRNA}$. In female mice, $Y b x 2$ is expressed exclusively in the oocyte and encodes a very abundant protein that stabilizes maternal mRNA, sustains protein synthesis and is required for normal spindle formation (Yu et al. 2001, 2002, 2004, Medvedev et al. 2011). Mice null for Ybx2 are infertile (Yang et al. 2005) and adult mice are characterized by degeneration and loss of oocytes. Interestingly, in juvenile $\mathrm{Ybx}^{--}$mice, with a less pronounced loss of oocytes, follicles were unable to ovulate in response to exogenous gonadotrophin (Yang et al. 2005), suggesting that Ybx2 may play some role in oocyte signalling to the cumulus cells and the mechanism of ovulation. In cattle, YBX2 protein levels decrease from the germinal vesicle stage to meiosis II (Vigneault et al. 2009). Although speculative, the present data suggest that KITL may enhance YBX2 action in the bovine oocyte, contributing for RNA stability and protein production during the maternal-embryo transition and for normal spindle formation/meiosis completion.

In summary, the present data show that KITL mRNA levels increase during IVM in cattle, and that addition of KITL1 to COC enhances resumption of meiosis. Two potential mechanisms by which KITL may increase oocyte maturation are by inhibiting the expression of NPPC, a factor that maintains meiotic arrest, and by increasing expression of YBX2, an oocyte-specific protein essential for ovulation and oocyte health. In addition, we provide evidence that the oocyte regulates the expression of KITL and NPPC in cumulus cells, suggesting a novel mechanism by which the oocyte may influence its own fate.

\section{Declaration of interest}

The authors declare that there is no conflict of interest that could be perceived as prejudicing the impartiality of the research reported.

\section{Funding}

This work was supported by the Fundação de Amparo à Pesquisa do Estado de São Paulo (FAPESP), the Conselho Nacional de Desenvolvimento Científico e Tecnológico (CNPq, Brazil).

\section{References}

Brannan CI, Lyman SD, Williams DE, Eisenman J, Anderson DM, Cosman D, Bedell MA, Jenkins NA \& Copeland NG 1991 Steel-Dickie mutation encodes a c-kit ligand lacking transmembrane and cytoplasmic domains. PNAS 88 4671-4674. (doi:10.1073/pnas.88.11.4671)

Buccione R, Vanderhyden BC, Caron PJ \& Eppig JJ 1990 FSH-induced expansion of the mouse cumulus oophorus in vitro is dependent upon a specific factor(s) secreted by the oocyte. Developmental Biology 138 16-25. (doi:10.1016/0012-1606(90)90172-F)

Caixeta ES, Machado MF, Ripamonte P, Price C \& Buratini J 2013a Effects of FSH on the expression of receptors for oocyte-secreted factors and members of the EGF-like family during in vitro maturation in cattle. Reproduction, Fertility, and Development 25 890-899. (doi:10.1071/ RD12125)

Caixeta ES, Sutton-McDowall ML, Gilchrist RB, Thompson JG, Price CA, Machado MF, Lima PF \& Buratini J 2013b Bone morphogenetic protein 15 and fibroblast growth factor 10 enhance cumulus expansion, glucose uptake, and expression of genes in the ovulatory cascade during in vitro maturation of bovine cumulus-oocyte complexes. Reproduction 146 27-35. (doi:10.1530/REP-13-0079)

Celestino JJ, Bruno JB, Lima-Verde IB, Matos MH, Saraiva MV, Chaves RN, Martins FS, Almeida AP, Cunha RM, Lima LF et al. 2010 Steady-state level of kit ligand mRNA in goat ovaries and the role of kit ligand in preantral follicle survival and growth in vitro. Molecular Reproduction and Development 77 231-240.

Crawford JL \& MCNatty KP 2012 The ratio of growth differentiation factor 9: bone morphogenetic protein $15 \mathrm{mRNA}$ expression is tightly co-regulated and differs between species over a wide range of ovulation rates. Molecular and Cellular Endocrinology 348 339-343. (doi:10.1016/j. mce.2011.09.033)

De Cesaro MP, Macedo MP, Santos JT, Rosa PR, Ludke CA, Rissi VB, Gasperin BG \& Gonçalves PB 2015 Natriuretic peptides stimulate oocyte meiotic resumption in bovine. Animal Reproduction Science 159 52-59. (doi:10.1016/j.anireprosci.2015.05.012)

Eppig J 2005 Mouse oocytes control metabolic co-operativity between oocytes and cumulus cells. Reproduction, Fertility, and Development 17 1-2. (doi:10.1071/RDv17n2paperabs)

Franciosi F, Coticchio G, Lodde V, Tessaro I, Modina SC, Fadini R, Dal Canto M, Renzini MM, Albertini DF \& Luciano AM 2014 Natriuretic peptide precursor $\mathrm{C}$ delays meiotic resumption and sustains gap junctionmediated communication in bovine cumulus-enclosed oocytes. Biology of Reproduction 91 61. (doi:10.1095/biolreprod.114.118869)

Huang EJ, Nocka KH, Buck J \& Besmer P 1992 Differential expression and processing of two cell associated forms of the kit-ligand: KL-1 and KL-2. Molecular Biology of the Cell 3 349-362. (doi:10.1091/mbc.3.3.349) 
Hussein TS, Froiland DA, Amato F, Thompson JG \& Gilchrist RB 2005 Oocytes prevent cumulus cell apoptosis by maintaining a morphogenic paracrine gradient of bone morphogenetic proteins. Journal of Cell Science 118 5257-5268. (doi:10.1242/jcs.02644)

Hutt KJ, McLaughlin EA \& Holland MK 2006 Kit ligand and c-Kit have diverse roles during mammalian oogenesis and folliculogenesis. Molecular Human Reproduction 12 61-69. (doi:10.1093/molehr/gal010)

Hyttel P, Xu KP, Smith S \& Greve T 1986 Ultrastructure of in-vitro oocyte maturation in cattle. Journal of Reproduction and Fertility 78 615-625. (doi:10.1530/jrf.0.0780615)

Ismail RS, Okawara Y, Fryer JN \&Vanderhyden BC 1996 Hormonal regulation of the ligand for c-kit in the rat ovary and its effects on spontaneous oocyte meiotic maturation. Molecular Reproduction and Development 43 458-469. (doi:10.1002/(SICI)1098-2795(199604)43:4\&lt;458::AIDMRD8\&gt;3.0.CO;2-O)

Ismail RS, Dubé M \& Vanderhyden BC 1997 Hormonally regulated expression and alternative splicing of kit ligand may regulate kitinduced inhibition of meiosis in rat oocytes. Developmental Biology $\mathbf{1 8 4}$ 333-342. (doi:10.1006/dbio.1997.8531)

Joyce IM, Pendola FL, Wigglesworth K \& Eppig JJ 1999 Oocyte regulation of kit ligand expression in mouse ovarian follicles. Developmental Biology 214 342-353. (doi:10.1006/dbio.1999.9437)

Joyce IM, Clark AT, Pendola FL \& Eppig JJ 2000 Comparison of recombinant growth differentiation factor-9 and oocyte regulation of KIT ligand messenger ribonucleic acid expression in mouse ovarian follicles. Biology of Reproduction 63 1669-1675. (doi:10.1095/ biolreprod63.6.1669)

Kawaguchi N, Horiuchi K, Becherer JD, Toyama Y, Besmer P \& Blobel CP 2007 Different ADAMs have distinct influences on Kit ligand processing: phorbol-ester-stimulated ectodomain shedding of Kitl 1 by ADAM17 is reduced by ADAM19. Journal of Cell Science 120 943-952. (doi:10.1242/jcs.03403)

Kawamura K, Cheng Y, Kawamura N, Takae S, Okada A, Kawagoe Y, Mulders S, Terada Y \& Hsueh AJ 2011 Pre-ovulatory LH/hCG surge decreases C-type natriuretic peptide secretion by ovarian granulosa cells to promote meiotic resumption of pre-ovulatory oocytes. Human Reproduction 26 3094-3101. (doi:10.1093/humrep/der282)

Lee KB, Zhang M, Sugiura K, Wigglesworth K, Uliasz T, Jaffe LA \& Eppig JJ 2013 Hormonal coordination of natriuretic peptide type $\mathrm{C}$ and natriuretic peptide receptor 3 expression in mouse granulosa cells. Biology of Reproduction 88 42. (doi:10.1095/ biolreprod.112.104810)

Liu X, Xie F, Zamah AM, Cao B \& Conti M 2014 Multiple pathways mediate luteinizing hormone regulation of CGMP signalling in the mouse ovarian follicle. Biology of Reproduction 919. (doi:10.1095/ biolreprod.113.116814)

Lodde V, Modina S, Galbusera C, Franciosi F \& Luciano AM 2007 Largescale chromatin remodeling in germinal vesicle bovine oocytes: interplay with gap junction functionality and developmental competence. Molecular Reproduction and Development 74 740-749. (doi:10.1002/ mrd.20639)

Lodde V, Modina S, Maddox-Hyttel P, Franciosi F, Lauria A \& Luciano AM 2008 Oocyte morphology and transcriptional silencing in relation to chromatin remodeling during the final phases of bovine oocyte growth. Molecular Reproduction and Development 75 915-924. (doi:10.1002/ mrd.20824)

Machado MF, Portela VM, Price CA, Costa IB, Ripamonte P, Amorim RL \& Buratini J 2009 Regulation and action of fibroblast growth factor 17 in bovine follicles. Journal of Endocrinology 202 347-353 (doi:10.1677/ JOE-09-0145)

Machado MF, Caixeta ES, Sudiman J, Gilchrist RB, Thompson JG, Lima PF, Price CA \& Buratini J 2015 Fibroblast growth factor 17 and bone morphogenetic protein 15 enhance cumulus expansion and improve quality of in vitro-produced embryos in cattle. Theriogenology $\mathbf{8 4}$ 390-398. (doi:10.1016/j.theriogenology.2015.03.031)

Marei WF, Abayasekara DR, Wathes DC \& Fouladi-Nashta AA 2014 Role of PTGS2-generated PGE2 during gonadotrophin-induced bovine oocyte maturation and cumulus cell expansion. Reproductive Biomedicine Online 28 388-400. (doi:10.1016/j.rbmo.2013.11.005)

Medvedev S, Pan H \& Schultz RM 2011 Absence of MSY2 in mouse oocytes perturbs oocyte growth and maturation, RNA stability, and the transcriptome. Biology of Reproduction 85 575-583. (doi:10.1095/ biolreprod.111.091710)
Miyoshi T, Otsuka F, Nakamura E, Inagaki K, Ogura-Ochi K, Tsukamoto N, Takeda M \& Makino H 2012 Regulatory role of kit ligand-c-kit interaction and oocyte factors in steroidogenesis by rat granulosa cells. Molecular and Cellular Endocrinology 358 18-26. (doi:10.1016/j.mce.2012.02.011)

Mottershead DG, Sugimura S, Al-Musawi SL, Li JJ, Richani D, White MA, Martin GA, Trotta AP, Ritter LJ, Shi J et al. 2015 Cumulin, an Oocytesecreted heterodimer of the transforming growth factor- $\beta$ family, is a potent activator of granulosa cells and improves oocyte quality. Journal of Biological Chemistry 290 24007-24020. (doi:10.1074/jbc. M115.671487)

Norris RP, Ratzan WJ, Freudzon M, Mehlmann LM, Krall J, Movsesian MA, Wang H, Ke H, Nikolaev VO \& Jaffe LA 2009 Cyclic GMP from the surrounding somatic cells regulates cyclic AMP and meiosis in the mouse oocyte. Development 136 1869-1878. (doi:10.1242/dev.035238)

Otsuka F \& Shimasaki S 2002 A negative feedback system between oocyte bone morphogenetic protein 15 and granulosa cell kit ligand: its role in regulating granulosa cell mitosis. PNAS 99 8060-8065. (doi:10.1073/ pnas.122066899)

Packer AI, Hsu YC, Besmer P \& Bachvarova RF 1994 The ligand of the c-kit receptor promotes oocyte growth. Developmental Biology 161 194-205. (doi:10.1006/dbio.1994.1020)

Paradis F, Moore HS, Pasternak JA, Novak S, Dyck MK, Dixon WT \& Foxcroft GR 2010 Pig preovulatory oocytes modulate cumulus cell protein and gene expression in vitro. Molecular and Cellular Endocrinology 320 87-96. (doi:10.1016/j.mce.2010.01.034)

Pfaffl MW 2001 A new mathematical model for relative quantification in real-time RT-PCR. Nucleic Acids Research 29 e45. (doi:10.1093/ nar/29.9.e45)

Prochazka R, Blaha M \& Nemcova L 2012 Signaling pathways regulating FSH- and amphiregulin-induced meiotic resumption and cumulus cell expansion in the pig. Reproduction 144 535-546. (doi:10.1530/REP-120191)

Ralph JH, Telfer EE \& Wilmut I 1995 Bovine cumulus cell expansion does not depend on the presence of an oocyte secreted factor. Molecular Reproduction and Development 42 248-253. (doi:10.1002/ mrd.1080420214)

Regassa A, Rings F, Hoelker M, Cinar U, Tholen E, Looft C, Schellander K \& Tesfaye D 2011 Transcriptome dynamics and molecular crosstalk between bovine oocyte and its companion cumulus cells. BMC Genomics 12 57. (doi:10.1186/1471-2164-12-57)

Reizel Y, Elbaz J \& Dekel N 2010 Sustained activity of the EGF receptor is an absolute requisite for $\mathrm{LH}$-induced oocyte maturation and cumulus expansion. Molecular Endocrinology 24 402-411. (doi:10.1210/ me.2009-0267)

Richards JS 2005 Ovulation: new factors that prepare the oocyte for fertilization. Molecular and Cellular Endocrinology 234 75-79. (doi:10.1016/j.mce.2005.01.004)

Robinson JW, Zhang M, Shuhaibar LC, Norris RP, Geerts A, Wunder F, Eppig J, Potter LR \& Jaffe LA 2012 Luteinizing hormone reduces the activity of the NPR2 guanylyl cyclase in mouse ovarian follicles, contributing to the cyclic GMP decrease that promotes resumption of meiosis in oocytes. Developmental Biology 366 308-316. (doi:10.1016/j. ydbio.2012.04.019)

Shuhaibar LC, Egbert JR, Norris RP, Lampe PD, Nikolaev VO, Thunemann M, Wen L, Feil R \& Jaffe LA 2015 Intercellular signaling via cyclic GMP diffusion through gap junctions restarts meiosis in mouse ovarian follicles. PNAS 112 5527-5532. (doi:10.1073/pnas.1423598112)

Sugiura K, Pendola FL \& Eppig JJ 2005 Oocyte control of metabolic cooperativity between oocytes and companion granulosa cells: energy metabolism. Developmental Biology 279 20-30. (doi:10.1016/j. ydbio.2004.11.027)

Sutton ML, Cetica PD, Beconi MT, Kind KL, Gilchrist RB \& Thompson JG 2003 Influence of oocyte-secreted factors and culture duration on the metabolic activity of bovine cumulus cell complexes. Reproduction 126 27-34. (doi:10.1530/rep.0.1260027)

Thomas FH \& Vanderhyden BC 2006 Oocyte-granulosa cell interactions during mouse follicular development: regulation of kit ligand expression and its role in oocyte growth. Reproductive Biology and Endocrinology 4 19. (doi:10.1186/1477-7827-4-19)

Thomas FH, Ethier JF, Shimasaki S \& Vanderhyden BC 2005 Folliclestimulating hormone regulates oocyte growth by modulation of expression of oocyte and granulosa cell factors. Endocrinology $\mathbf{1 4 6}$ 941-949. (doi:10.1210/en.2004-0826) 
Thomas FH, Ismail RS, Jiang JY \& Vanderhyden BC 2008 Kit ligand 2 promotes murine oocyte growth in vitro. Biology of Reproduction $\mathbf{7 8}$ 167-175. (doi:10.1095/biolreprod.106.058529)

Vanderhyden BC 1993 Species differences in the regulation of cumulus expansion by an oocyte-secreted factor(s). Journal of Reproduction and Fertility 98 219-227. (doi:10.1530/jrf.0.0980219)

Vigneault C, McGraw S \& Sirard MA 2009 Spatiotemporal expression of transcriptional regulators in concert with the maternal-to-embryonic transition during bovine in vitro embryogenesis. Reproduction 137 13-21. (doi:10.1530/REP-08-0077)

Yang J, Medvedev S, Yu J, Tang LC, Agno JE, Matzuk MM, Schultz RM \& Hecht NB 2005 Absence of the DNA-/RNA-binding protein MSY2 results in male and female infertility. PNAS 102 5755-5760. (doi:10.1073/ pnas.0408718102)

Ye Y, Kawamura K, Sasaki M, Kawamura N, Groenen P, Gelpke MD, Rauch R, Hsueh AJ \& Tanaka T 2009 Kit ligand promotes first polar body extrusion of mouse preovulatory oocytes. Reproductive Biology and Endocrinology 7 26. (doi:10.1186/1477-7827-7-26)

Yu J, Hecht NB \& Schultz RM 2001 Expression of MSY2 in mouse oocytes and preimplantation embryos. Biology of Reproduction 65 1260-1270. (doi:10.1095/biolreprod65.4.1260)

Yu J, Hecht NB \& Schultz RM 2002 RNA-binding properties and translation repression in vitro by germ cell-specific MSY2 protein. Biology of Reproduction 67 1093-1098. (doi:10.1095/biolreprod67.4.1093)
Yu J, Deng M, Medvedev S, Yang J, Hecht NB \& Schultz RM 2004 Transgenic RNAi-mediated reduction of MSY2 in mouse oocytes results in reduced fertility. Developmental Biology 268 195-206. (doi:10.1016/j. ydbio.2003.12.020)

Zhang M, Su YQ, Sugiura K, Xia G \& Eppig JJ 2010a Granulosa cell ligand NPPC and its receptor NPR2 maintain meiotic arrest in mouse oocytes. Science 330 366-369. (doi:10.1126/science.1193573)

Zhang K, Hansen PJ \& Ealy AD 2010b Fibroblast growth factor 10 enhances bovine oocyte maturation and developmental competence in vitro. Reproduction 140 815-26. (doi:10.1530/REP-10-0190)

Zhou JH, Hikono H, Ohtaki M, Kubota T \& Sakurai M 1994 Cloning and characterization of cDNAs encoding two normal isoforms of bovine stem cell factor. Biochimica et Biophysica Acta 1223 148-150. (doi:10.1016/0167-4889(94)90084-1)

Received 23 March 2016

First decision 23 May 2016

Revised manuscript received 11 July 2016

Accepted 4 August 2016 